\title{
Identification of single nucleotide polymorphisms in GDF9 gene associated with litter size in Garut sheep
}

\author{
Resti Yuliana Rahmawati ${ }^{1}$, Sumadi $^{1}$, and Tety Hartatik ${ }^{1,{ }^{*}}$ \\ ${ }^{1}$ Department of Animal Breeding and Reproduction, Faculty of Animal Science, Universitas Gadjah Mada, Jalan Fauna 03, Bulaksumur, \\ Yogyakarta 55281, Indonesia \\ *Corresponding author: tety@ugm.ac.id
}

SUBMITTED 24 December 2018 REVISED 20 May 2019 ACCEPTED 20 June 2019

\begin{abstract}
The growth differentiation factor 9 (GDF9) gene has been regarded as having major impacts on ovulation rate and litter size in sheep. The aim of this study was to identify the single nucleotide polymorphisms (SNPs) of the GDF9 gene and their association with litter size in Garut sheep. For this purpose, a total of 60 ewes of Garut sheep were included in this study. Based on the sheep GDF9 reference sequences (Genbank Acc. No. AF078545.2), one pair of primers (5'-CTGCTGTTTAACCTGGATCGTG-3 5'-GGAGAGCCATACCGATGTCC-3 as forward and reverse, respectively) was used for PCR amplification. The results revealed that four SNPs (g.54C>T, g.60G >A, g.304G >A, and g.333G >A) were found in Garut sheep by direct sequencing. For SNP g.54C $>$ T, the sheep exhibited the highest frequency of allele $C$ and genotype $C C$. On the other hand, SNPs g.60G >A, g.304G>A, and g.333G>A showed a higher frequency of allele G than allele A, and the GG genotype was predominant in the population. SNP g.333G>A had a significant effect on litter size $(p<0.05)$, and ewes with the GG genotype had a higher litter size than those with the GA genotype. Genotype distributions for all identified SNPs were in agreement with Hardy-Weinberg equilibrium. We highlight that SNP g.333G>A may be useful as a genetic marker for litter size in Garut sheep.
\end{abstract}

KEYWORDS Garut sheep; GDF9 gene; prolificacy; single nucleotide polymorphism (SNP)

\section{Introduction}

Garut, a local sheep in Indonesia, is mainly used as fighting art as well as a meat producer. Because of its important roles for local communities, its population should be increased (Heriyadi 2005). With the aim of increasing sheep populations in Indonesia and improving the reproductive traits of Garut sheep, it is necessary to detect the genetic variation of these sheep in terms of their reproductive traits. A substantial amount of genetic variation will provide the possibility for genetic improvement. In Garut sheep farming, litter size is a major concern with regards to profitability. Litter size depends on the number of ovum ovulated by ewes. To date, genetic improvement of reproductive traits in many sheep breeds in Indonesia has mainly been based on the use of conventional breeding methods. Recently, the use of molecular techniques for livestock genetic improvement has provided better gains by enabling the identification of major genes related to reproductive traits that can be further utilized as a markerassisted selection in sheep breeding.

The prolificacy is controlled by multiple genes, which are characterized as fertility genes (Davis 2004). The members of the transforming growth factor- $\beta$ (TGF- $\beta$ ) superfamily, including bone morphogenic protein 15
(BMP15), growth differentiation factor 9 (GDF9), and bone morphogenic protein-IB have been proved to play a crucial role in follicular growth and ovulation rate (Kasiriyan et al. 2009). Furthermore, as reported in several studies, GDF9, BMP1, BMPR1B, and leptin are considered to be major genes affecting prolificacy (Chen et al. 2005; Polley et al. 2009; Pokharel et al. 2018). Reproduction quality in sheep is determined by a number of factors, including feed quality, environmental conditions, and ovulation, the latter of which begins with folliculogenesis that involves the roles of several hormones and genes, such as GDF9 and BMP15 genes. GDF9 has been mapped to sheep chromosome 5 (Hanrahan et al. 2004). It spans approximately 5644 bp (Genbank Acc. No. AF078545.2) and contains two exons and one intron. In addition, GDF9 is a growth factor and a member of the TGF- $\beta$ superfamily that is secreted by oocytes in growing ovarian follicles (Hanrahan et al. 2004). It also acts as a simulator in primary-follicle development until ovulation, and makes major contributions to the animal's prolificacy (Gilchrist et al. 2008; Goyal et al. 2017; Wang et al. 2018). In female mammalian reproduction, growth and differentiation factors play important roles during early folliculogenesis (Elvin et al. 1999). In the ovary, GDF9 is exclusively expressed, specifically in the oocytes of humans (Vitt et al. 
2000), cattle (Bodensteiner et al. 2000), mice (McGrath et al. 1995; Dube et al. 1998; Lan 2003), and sheep (Bodensteiner et al. 2000; Juengel et al. 2002).

Many researchers have shown great interest in the investigation of major genes related to ovulation rate and prolificacy in sheep. He et al. (2010) found one point mutation of the GDF9 gene in Chinese goats that is associated with ovulation rate. Many significant associations have been reported between GDF9 polymorphism and ovulation rate, prolificacy, and fertility in sheep (Hanrahan et al. 2004; Ghaffari et al. 2010; Ghaderi et al. 2010; Souza et al. 2014; Mullen and Hanrahan 2014; Khodabakhshzadeh et al. 2016; Ahmad et al. 2017). Moreover, current investigations in sheep, humans, and rodents show that the GDF9 and BMP15 genes can be regarded as important genes associated with prolificacy in mammals (McNatty et al. 2005). However, there is no report on the genetic variation of the GDF9 gene in Garut sheep. Therefore, the aim of this study was to identify the single nucleotide polymorphisms (SNPs) in Garut sheep. Identification of the GDF9 gene polymorphism can be very useful in better understanding the genetic mechanisms of prolificacy in sheep, and the results of this study are expected to be valuable as genetic markers for further studies, as well for future genetic improvement of Garut sheep.

\section{Materials and methods}

\subsection{Sample collection and DNA extraction}

A total of sixty ewes of Garut sheep raised in UPTDBBTDK Margawati, Garut, Java, Indonesia, were used in this study. The animals were sampled based on their birth type (single, twin and, triple) with 20 samples per type. Blood samples, approximately $3 \mathrm{~mL}$, were collected from the jugular vein of each ewe in EDTA vacutainer tubes and held on ice until delivery to the laboratory. Genomic DNA was extracted using the gSYNCTMDNA Extraction Kit (Geneaid, New Taipei City, Taiwan).

\subsection{Primer design and DNA amplification}

The primer design was carried out based on a previous report by Hartatik (2016), in oligoprimer primer3 (http://primer3.ut.ee) using Genbank sequence AF078545.2 as a template, DQ301499.1, NM_001142888.2, KT853039.1, and FJ429111.1. One pair of primers (5'-CTGCTGTTTAACCTGGATCGTG-3 and 5'-GGAGAGCCATACCGATGTCC-3 as the forward and reverse primer, respectively) was designed to amplify a 770 bp product of the GDF9 gene, which is located between 3326 and 4095 bp based on the GDF9 reference sequence (AF078545.2). PCR was performed in a 30 $\mu \mathrm{L}$ volume containing $2 \mu \mathrm{L}$ genomic DNA, $15 \mu \mathrm{L}$ KAPA2G Fast Ready Mix PCR Kit (Kapa Biosystems, Wilmington, United States), $1.5 \mu \mathrm{L}$ of each primer, and $10 \mu \mathrm{L}$ aquabidest. The PCR conditions were $94^{\circ} \mathrm{C}$ for 5 min and 35 cycles of $5 \mathrm{~s}$ at $94^{\circ} \mathrm{C}, 40 \mathrm{~s}$ at $59^{\circ} \mathrm{C}, 30 \mathrm{~s}$ at $72^{\circ} \mathrm{C}$, and a final step of $5 \mathrm{~min}$ at $72^{\circ} \mathrm{C}$ (Hanrahan et al. 2004).

\subsection{Sequencing and SNPs identification}

Thirty microliters $(30 \mu \mathrm{L})$ of each PCR product were sent to $1^{\text {st }}$ Base Sequencing Laboratories (Selangor, Malaysia) for direct sequencing. Sequence analysis and alignment were carried out using Bioedit version 7.2.5 in order to identify polymorphisms of the GDF9 gene. The genotype of each ewe was determined based on the sequencing results. We analyzed the electropherogram of each sample, where a heterozygous genotype should appear as double peaks in the BioEdit software.

\subsection{Statistical analysis}

Allelic and genotypic frequencies were calculated by direct counting, and their distributions were tested for Hardy-Weinberg equilibrium with chi-square analysis using Equation 1 (Falconer et al. 1996):

$$
\chi^{2}=\sum_{i=1}^{n} \frac{\left(O_{i}-E_{i}\right)^{2}}{E_{i}}
$$

where $\chi^{2}$ is the chi-square, $O_{i}$ is the observed frequencies, $E_{i}$ is the expected frequencies and $n$ is the number of measurements. The association between GDF9 genotypes and litter size was analyzed using analysis of variance (ANOVA) with the mathematical model shown in Equation 2:

$$
Y_{i j}=\mu+T_{i}+\varepsilon_{i j}
$$

where $\mu$ is the overall mean, $T_{i}$ is the genotype effect of the GDF9 gene and $\varepsilon_{i j}$ is a random residual effect.

\section{Results and discussion}

\subsection{PCR amplification and SNPs detection}

Using a pair of specific primers, we successfully amplified a 770 bp fragment of the GDF9 gene for 59 samples, and the size of the PCR products in gel electrophoresis was the same as expected (Figure 1). In gel electrophoresis, a clear band indicated a good quality of DNA samples. In contrast, smeared bands may indicate poor sample quality, and that the DNA samples are contaminated with protein, especially during the extraction process (Yuwono 2006; Novitasari et al. 2014; Widyastuti 2017). The PCR

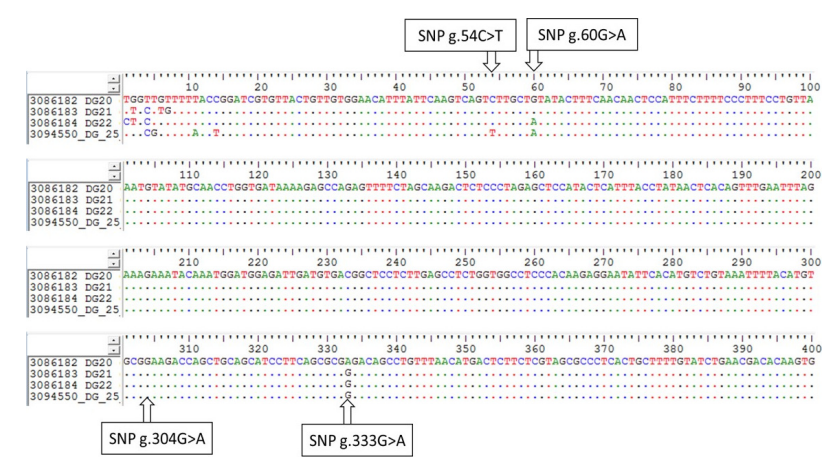

FIGURE 1 Alignment of the GDF9 gene sequences. 
products of each sample were further subjected to direct sequencing.

Based on the sequencing results, the GDF9 gene sequences of 59 samples were aligned (Figure 2). A total of four SNPs (g.54C>T, g.60G>A, g.304G $>$ A, and g.333G $>$ A) were identified. Accordingly, we determined four types of ewes with different genotype combinations (Table 1. Type A consisted of five ewes (8\%), one ewe (2\%), and one ewe (1\%) having a birth type of single, twin, and triple, respectively. Type B consisted of 13 ewes (22\%), 17 ewes (29\%), and 16 ewes (27\%) having a birth type of single, twin, and triple, respectively. Type C consisted of one ewe (2\%) having a single birth type. Type D consisted of one ewe (2\%), one ewe (2\%), and three ewes (5\%) having a birth type of single, twin, and triple, respectively. Initially, Hanrahan et al. (2004) observed eight polymorphisms in the entire coding region of the sheep GDF9 gene. Later investigation by Bahrami et al. (2014) and Khodabakhshzadeh et al. (2016) also detected some point mutations (SNP) in the GDF9 gene located in exon 1 and exon 2, respectively. Four mutations detected in the present study indicated that the GDF9 gene in Garut sheep was found to be polymorphic.

The results of the allelic and genotypic frequencies and chi-square test of each SNP of the GDF9 gene are presented in Table 2. For SNP g.54C>T, Garut sheep exhibited the highest frequency of allele $\mathrm{C}$ and genotype CC. On the other hand, SNPs g.60G $>$ A, g.304G $>$ A, and g.333G $>A$ showed a higher frequency of allele $G$ than al-

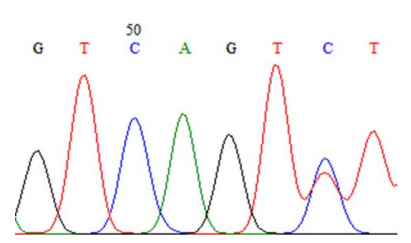

(a)

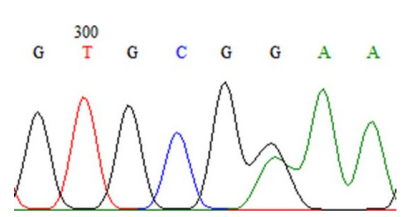

(c)

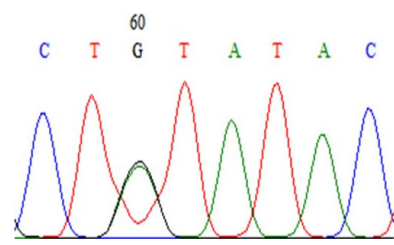

(b)

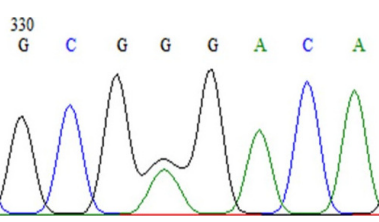

(d)
FIGURE 2 Electropherogram of the GDF9 sequences: a) SNP g.54C > T; b) SNP g.60G>A; c) SNP g.304G>A; d) SNP g.333G>A. lele A, and the GG genotype was predominant in the population. These results agreed with the findings reported by Ghaderi et al. (2010) in Iranian sheep and Polley et al. (2009) in Garole sheep; they reported that homozygous animals for the GDF9 mutation were predominant in both populations. In this study, we also analyzed the genotype distribution of the GDF9 gene using a chi-square test $\left(\chi^{2}\right)$. The $\chi^{2}$ test was performed to verify whether the genotype distribution of the GDF9 gene in the studied population agreed with Hardy-Weinberg equilibrium expectations. The results showed that genotype distributions of the GDF9 gene polymorphisms in Garut sheep were in accordance with Hardy-Weinberg equilibrium.

\subsection{SNPs marker association with litter size}

The GDF9 gene polymorphisms detected in the present study were associated with litter size. The results of association analysis are presented in Table 3. Among the four SNPs, only SNP g.333G $>$ A had a significant effect on litter size $(p<0.05)$. Ewes with the GG genotype had a larger litter size than those with the GA genotype.

Varying patterns of inheritance are detected to have an association with the GDF9 gene. Several studies reported that GDF9 gene polymorphisms are associated with sterility and increased ovulation rate in sheep. Hanrahan et al. (2004) reported a number of mutations of the GDF9 and BMP15 genes in the Cambridge and F700-Belclare breeds. They concluded that an increased ovulation rate in heterozygous carriers and sterility in homozygous carriers in both breeds are associated with mutations in the GDF9 and BMP15 genes. As reported by Paz et al. (2014) and Javanmard et al. (2011), ewes with the homozygous genotype had a larger litter size than those with the heterozygous genotype. In contrast, although Arta and Rahayu (2013) detected polymorphisms in the bovine GDF9 gene, these polymorphisms are not associated with the success of artificial insemination in Peranakan Ongole cattle. Among the four SNPs identified in the present study, only SNP g.333G > A of the GDF9 gene can be used as a markerassisted selection in Garut sheep.

The GDF9 gene is an important candidate gene for the primary ovarian insufficiency. Expressed in oocytes, its characteristics are like those of BMP15, a member of the TGF gene family. Ovulation is a complex mechanism that may differ among individuals, depending on either genetic or environmental factors. In sheep, the ewe's repro-

TABLE 1 Four types of ewes based on the identified SNPs.

\begin{tabular}{ccccccccc}
\hline \multirow{2}{*}{ Type } & \multicolumn{3}{c}{ No. of ewes } & SNPg.54C $>$ T & SNPg.60G >A & SNPg.304G >A & SNP g.333G >A \\
\cline { 2 - 5 } & Single birth & Double birth & Triple birth & & & & \\
\hline A & 5 & 1 & 1 & CC & GA & GG & GA \\
B & 13 & 17 & 16 & CC & GG & GG & GG \\
C & 1 & 0 & 0 & CT & AA & GA & GA \\
D & 1 & 1 & 3 & CT & GA & GA & GG \\
\hline
\end{tabular}


TABLE 2 Allelic and genotypic frequency and chi-square test.

\begin{tabular}{|c|c|c|c|c|c|c|c|}
\hline \multirow{2}{*}{$\begin{array}{l}\text { SNP } \\
\text { g.54C>T }\end{array}$} & \multirow{2}{*}{$\begin{array}{l}\text { Total } \\
\text { Observed }\end{array}$} & \multicolumn{3}{|c|}{ Genotype } & \multicolumn{2}{|c|}{ Allele } & \multirow{2}{*}{$\frac{\chi^{2}}{0.12}$} \\
\hline & & 54.00 (CC) & $5.00(\mathrm{CT})$ & $0.00(\mathrm{TT})$ & $0.96(\mathrm{C})$ & $0.04(T)$ & \\
\hline & Expected & $54.11(\mathrm{CC})$ & $4.79(\mathrm{CT})$ & $0.11(\mathrm{TT})$ & & & \\
\hline \multirow[t]{2}{*}{ g.60G >A } & Observed & 46.00 (GG) & 12.00 (GA) & $1.00(\mathrm{AA})$ & $0.88(G)$ & $0.12(\mathrm{~A})$ & 0.05 \\
\hline & Expected & 45.83 (GG) & 12.33 (GA) & $0.83(\mathrm{AA})$ & & & \\
\hline \multirow[t]{2}{*}{ g. $304 G>A$} & Observed & 53.00 (GG) & 6.00 (GA) & $0.00(\mathrm{AA})$ & $0.95(\mathrm{G})$ & $0.05(\mathrm{~A})$ & 0.17 \\
\hline & Expected & 53.15 (GG) & 5.69 (GA) & $0.15(\mathrm{AA})$ & & & \\
\hline \multirow[t]{2}{*}{ g. $333 G>A$} & Observed & 51.00 (GG) & 8.00 (GA) & $0.00(\mathrm{AA})$ & $0.93(\mathrm{G})$ & $0.07(\mathrm{~A})$ & 0.31 \\
\hline & Expected & 51.27 (GG) & 7.46 (GA) & 0.27 (AA) & & & \\
\hline
\end{tabular}

$\chi^{2} 0.05 ; 2=5.99$

TABLE 3 Association results between genotypes of the sheep GDF9 gene and litter size.

\begin{tabular}{lccl}
\hline SNP & Genotype & No. of ewes & Litter size \\
\hline g.54C>T & CC & 53 & $1.98 \pm 0.82$ \\
g.60G >A & CT & 6 & $2.17 \pm 0.98$ \\
& GG & 46 & $2.06 \pm 0.80$ \\
& GA & 12 & $1.83 \pm 0.94$ \\
g.304G>A & AA & 1 & 1.00 \\
& GG & 53 & $1.98 \pm 0.82$ \\
g.333G>A & GA & 6 & $2.17 \pm 0.98$ \\
& GG & 51 & $2.09 \pm 0.81^{\mathrm{a}}$ \\
& GA & 8 & $1.37 \pm 0.74^{\mathrm{b}}$ \\
\hline
\end{tabular}

a,b Mean with different superscript within the same column differ significantly $(p<0.05)$.

ductive efficiency is commonly affected by its prolificacy trait. Prolificacy is a descriptor for the ability of ewe to produce a certain litter size in each parturition. Prolificacy is genetically inherited, and thus, genes encoding this trait must be identified for future sheep genetic improvement strategies. In sheep farming, prolificacy is an economic trait that determines profitability in sheep production. In genetic improvement strategies, a selection program is needed to improve some economic traits. Litter size is included as an important trait enhancing the productivity of sheep (Mishra 2014).

The investigation of candidate genes associated with economic traits is a crucial step in animal breeding. Ovis aries genome research and the detection of polymorphic sites of genes encoding economic traits are useful tasks for mapping and marker-assisted selection. The investigation of candidate genes concerned with economic traits will provide the possibility for the genetic improvement and modification of the desired traits. Molecular analysis is an important element in the utilization of genes encoding the economic traits of a given livestock species. In the sheep industry, many of the identified SNPs markers were found to be useful tools for determining the genetic basis for prolificacy traits in many breeds.
In this study, we found that SNP g.333G>A of the GDF9 gene may play an important role in the prolificacy trait, as indicated by higher levels of litter size in homozygous GG ewes compared with the heterozygous AG ewes. However, SNP g.333G>A did not change the amino acid encoded. Souza et al. (2014) detected a point mutation (c.943C > T) in the GDF9 gene of Brazilian sheep, resulting in a non-conservative amino acid change (p.Arg315Cys) in the cleavage site of the propeptide. In Belclare and Cambridge sheep, mutation in the GDF9 gene causes an amino acid substitution (S77F) that has been detected to have an impact on increased prolificacy (Hanrahan et al. 2004). Some previous studies reported that mutations in the GDF9 gene are associated with increased litter size in sheep (Davis 2004; Hanrahan et al. 2004; Liao et al. 2004)). In contrast, GDF9 gene polymorphisms detected in Shal sheep showed that the genetic basis for the twinning or multiple litter size is not associated with mutated alleles in the sheep GDF9 gene (Ghaffari et al. 2010). These reports suggest that the GDF9 gene may play an effective role in fertility and twinning in Garut sheep. However, for the future genetic improvement of Garut sheep, it is necessary to provide a suitable environment for these sheep. Furthermore, understanding the genetic basis concerned with litter size is a convenient and efficient tool in the selection program. Future genetic improvement of Garut sheep also requires further investigation of other SNPs or genes encoding the prolificacy traits, which is determined by multiple genes. According to the results of the present study, it can be highlighted that GDF9 gene polymorphism may affect twinning in Garut sheep.

\section{Conclusion}

It was clear that GDF9 gene polymorphisms were detected in Garut sheep. SNP g.333G>A was significantly associated with litter size. Thus, this SNP may prove to be valuable as a genetic marker for future work on the populations of Garut sheep.

\section{Acknowledgements}

We thank UPTD-BBTDK Margawati, Garut, for assisting in the collection of blood samples from breeding flocks. 
We are also grateful to Dwi Nur Happy Hariyono and three anonymous reviewers for their valuable suggestions on the manuscript.

\section{Authors' contributions}

$\mathrm{S}$ and TH were the supervisors of this research. They fully contributed to the guidance of this research and the improvement of the final manuscript of this article. RYR carried out the laboratory work, analyzed the data, and wrote the manuscript. All authors read and approved the final version of the manuscript.

\section{Competing interests}

The authors declare no competing interests.

\section{References}

Ahmad HI, Liu G, Jiang X, Edallew SG, Wassie T, Tasema B, Yun Y, Pan L, Liu C, Chong Y, Yu ZJ, Jilong H. 2017. Maximum-likelihood approaches reveal signatures of positive selection in BMP15 and GDF9 genes modulating ovarian function in mammalian female fertility. Ecol Evol. 7(21):8895-8902. doi:10.1002/ece3. 3336.

Arta PD, Rahayu S. 2013. Analisis polimorfisme gen growth differentiation factor 9 (GDF9) dan hubungannya dengan keberhasilan inseminasi buatan pada sapi PO [Analysis of GDF9 gene polymorphism and its relationship with the success of artificial insemination in Ongole cross-bred cattle]. Biotropika. 1(3):95-100.

Bahrami Y, Bahrami S, Mohammadi HR, Chekani-Azar V, Mousavizadeh SA. 2014. The polymorphism of GDF9 gene in Hisari sheep. Biol Forum. 6(2):46-52.

Bodensteiner KJ, McNatty KP, Clay CM, Moeller CL, Sawyer HR. 2000. Expression of growth and differentiation factor-9 in the ovaries of fetal sheep homozygous or heterozygous for the inverdale prolificacy gene (FecX I). Biol Reprod. 62(6):1479-1485. doi:10.1095/biolreprod62.6.1479.

Chen SY, Su YH, Wu SF, Sha T, Zhang YP. 2005. Mitochondrial diversity and phylogeographic structure of Chinese domestic goats. Mol Phylogenetics Evol. 37(3):804-814. doi:10.1016/j.ympev.2005.06.014.

Davis GH. 2004. Fecundity genes in sheep. Anim Reprod Sci. 82-83:247-253. doi:10.1016/j.anireprosci.2004. 04.001 .

Dube JL, Wang P, Elvin J, Lyons KM, Celeste AJ, Matzuk MM. 1998. The bone morphogenetic protein 15 gene is X-linked and expressed in oocytes. Mol Endocrinol. 12(12):1809-1817. doi:10.1210/mend.12.12.0206.

Elvin JA, Clark AT, Wang P, Wolfman NM, Matzuk MM. 1999. Paracrine actions of growth differentiation factor-9 in the mammalian ovary. Mol Endocrinol. 13(6):1035-1048. doi:10.1210/mend.13.6.0310.

Falconer DS, Mackay TFC, Frankham R. 1996. Introduction to quantitative genetics. $4^{\text {th }}$ edition. London: Longman Group.
Ghaderi A, Beigi Nasiri MT, Mirzadeh KH, Fayazi J, Sadr AS. 2010. Identification of the GDF9 mutation in two sheep breeds by using polymerase chain reaction- restriction fragment length polymorphism (PCR-RFLP) technique. African J Biotechnol. 9(47):8020-8022. doi:10.5897/ajb09.1924.

Ghaffari M, Nejati-Javaremi N, Rahimi-Mianji G. 2010. Lack of polymorphism in the oocyte derived growth factor (GDF9) gene in the Shal breed of sheep. S Afr J Anim Sci. 39(4). doi:10.4314/sajas.v39i4.51127.

Gilchrist RB, Lane M, Thompson JG. 2008. Oocytesecreted factors: regulators of cumulus cell function and oocyte quality. Hum Reprod Update. 14(2):159177. doi:10.1093/humupd/dmm040.

Goyal S, Aggarwal J, Dubey PK, Mishra BP, Ghalsasi P, Nimbkar C, Joshi BK, Kataria RS. 2017. Expression analysis of genes associated with prolificacy in FecB carrier and noncarrier Indian sheep. Anim Biotechnol. 28(3):220-227. doi:10.1080/10495398. 2016.1262869.

Hanrahan JP, Gregan SM, Mulsant P, Mullen M, Davis GH, Powell R, Galloway SM. 2004. Mutations in the genes for oocyte-derived growth factors GDF9 and BMP15 are associated with both increased ovulation rate and sterility in Cambridge and Belclare sheep (Ovis aries). Biol Reprod. 70(4):900-909. doi: 10.1095/biolreprod.103.023093.

Hartatik T. 2016. Pendekatan praktis deteksi polimorfisme DNA sapi Aceh [A practical approach to detection of Aceh cow DNA polymorphism]. Yogyakarta: UGM Press.

He Y, Ma X, Liu X, Zhang C, Li J. 2010. Candidate genes polymorphism and its association to prolificacy in Chinese goats. J Agric Sci. 2(1). doi:10.5539/jas. v2n1p88.

Heriyadi D. 2005. Identifikasi sifat-sifat kualitatif domba garut jantan tipe tangkas [identification of qualitative characteristics of agile type male garut sheep]. Jurnal Ilmu Ternak. 5(2):47-52.

Javanmard A, Azadzadeh N, Esmailizadeh AK. 2011. Mutations in bone morphogenetic protein 15 and growth differentiation factor 9 genes are associated with increased litter size in fat-tailed sheep breeds. Vet Res Commun. 35(3):157-167. doi:10.1007/ s11259-011-9467-9.

Juengel JL, Hudson NL, Heath DA, Smith P, Reader KL, Lawrence SB, O’Connell AR, Laitinen MP, Cranfield M, Groome NP, Ritvos O, McNatty KP. 2002. Growth differentiation factor 9 and bone morphogenetic protein 15 are essential for ovarian follicular development in sheep. Biol Reprod. 67(6):1777-1789. doi: 10.1095/biolreprod.102.007146.

Kasiriyan MM, Hafezeyan H, Sayahzadeh H, Jamshidi R, Asghari SR, Irajeyan GH, Buesagh H. 2009. Genetic polymorphism FecB and BMP15 genes and its association with litter size in Sangsari sheep breed of Iran. J Anim Vet Adv. 8(5):1025-1031. doi:10.3923/javaa. 2009.1025.1031. 
Khodabakhshzadeh R, Mohammadabadi M, Esmailizadeh A, Shahrebabak HM, Bordbar F, Namin SA. 2016. Identification of point mutations in exon 2 of GDF9 gene in Kermani sheep. Pol J Vet Sci. 19(2):281-289. doi:10.1515/pjvs-2016-0035.

Lan ZJ. 2003. GCNF-dependent repression of BMP-15 and GDF-9 mediates gamete regulation of female fertility. EMBO J. 22(16):4070-4081. doi:10.1093/ emboj/cdg405.

Liao WX, Moore RK, Shimasaki S. 2004. Functional and molecular characterization of naturally occurring mutations in the oocyte-secreted factors bone morphogenetic protein-15 and growth and differentiation factor-9. J Biol Chem. 279(17):17391-17396. doi: 10.1074/jbc.m401050200.

McGrath SA, Esquela AF, Lee SJ. 1995. Oocyte-specific expression of growth/differentiation factor-9. Mol Endocrinol. 9(1):131-136. doi:10.1210/mend.9.1. 7760846.

McNatty K, Smith P, Moore L, Reader K, Lun S, Hanrahan J, Groome N, Laitinen M, Ritvos O, Juengel J. 2005. Oocyte-expressed genes affecting ovulation rate. Mol Cell Endocrinol. 234(1-2):57-66. doi:10.1016/j.mce. 2004.08.013.

Mishra C. 2014. Genetic basis of prolificacy in sheep. Int J Livest Res. 4(1):46. doi:10.5455/ijlr. 20131227083421.

Mullen MP, Hanrahan JP. 2014. Direct evidence on the contribution of a missense mutation in GDF9 to variation in ovulation rate of Finnsheep. PLoS ONE. 9(4):e95251. doi:10.1371/journal.pone.0095251.

Novitasari DA, Elvyra R, Roslim DI. 2014. Teknik isolasi dan elektroforesis DNA total pada Kryptopterus apogon (Bleeker 1851) dari Sungai Kampar Kiri dan Tapung Hilir Kabupaten Kampar Provinsi Riau [Total DNA isolation and electrophoresis techniques on Kryptopterus apogon (Bleeker 1851) from Kampar Kiri River and Tapung Hilir River, Kampar District, Riau Province]. Jurnal Online Mahasiswa Bidang Matematika dan Ilmu Pengetahuan Alam. 1(2):5.

Paz E, Quiñones J, Bravo S, Montaldo HH, Sepúlveda N.
2014. Genotyping of BMPR1B, BMP15 and GDF9 genes in Chilean sheep breeds and association with prolificacy. Anim Genet. 46(1):98-99. doi:10.1111/ age.12254.

Pokharel K, Peippo J, Honkatukia M, Seppälä A, Rautiainen J, Ghanem N, Hamama TM, Crowe MA, Andersson M, Li MH, Kantanen J. 2018. Integrated ovarian mRNA and miRNA transcriptome profiling characterizes the genetic basis of prolificacy traits in sheep (Ovis aries). BMC Genomics. 19(104):1-17. doi:10.1186/s12864-017-4400-4.

Polley S, De S, Brahma B, Mukherjee A, PV V, Batabyal S, Arora JS, Pan S, Samanta AK, Datta TK, Goswami SL. 2009. Polymorphism of BMPR1b, BMP15 and GDF9 fecundity genes in prolific Garole sheep. Trop Anim Health Prod. 42(5):985-993. doi:10.1007/ s11250-009-9518-1.

Souza CJH, McNeilly AS, Benavides MV, Melo EO, Moraes JCF. 2014. Mutation in the protease cleavage site of GDF9 increases ovulation rate and litter size in heterozygous ewes and causes infertility in homozygous ewes. Anim Genet. 45(5):732-739. doi: 10.1111/age.12190.

Vitt UA, McGee EA, Hayashi M, Hsueh AJW. 2000. In vivo treatment with GDF-9 stimulates primordial and primary follicle progression and theca cell marker CYP17 in ovaries of immature rats. Endocrinology. 141(10):3814-3820. doi:10.1210/endo.141.10.7732.

Wang W, La Y, Zhou X, Zhang X, Li F, Liu B. 2018. The genetic polymorphisms of TGF- $\beta$ superfamily genes are associated with litter size in a Chinese indigenous sheep breed (Hu sheep). Anim Reprod Sci. 189:19-29. doi:10.1016/j.anireprosci.2017.12.003.

Widyastuti DA. 2017. Isolasi DNA kromosom Salmonella sp. dan visualisasinya pada elektroforesis gel agarosa [DNA isolation of Salmonella sp. chromosome and its visualization in the agarose gel electrophoresis]. Prosiding Seminar Nasional Pendidikan Biologi dan Saintek ke-2; Surakarta, Indonesia. p. 311-317.

Yuwono T. 2006. Teori dan aplikasi polymerase chain reaction. Yogyakarta: Andi Offset. 